\title{
The Level of History Teachers' Use Active Learning Methods and Technics
}

\author{
Sefa YILDIRIM ${ }^{1}$, Özkan AKMAN ${ }^{2} \&$ Bülent ALAGÖZ ${ }^{2}$ \\ ${ }^{1}$ The Faculty of Art and Science, History Department, Agri Ibrahim Cecen University, Agri, Turkey \\ ${ }^{2}$ Nizip of Education Faculty, Social Studies Education, Gaziantep University, Turkey \\ Correspondence: Sefa YILDIRIM, The Faculty of Art and Science, History Department, Agri Ibrahim Cecen \\ University, Agri, Turkey. Tel: 90-472-215-9994. E-mail: prehistory_tr@windowslive.com
}

Received: July 29, 2017 Accepted: August 30, $2017 \quad$ Online Published: November 28, 2017

doi:10.5539/ies.v10n12p140 URL: https://doi.org/10.5539/ies.v10n12p140

\begin{abstract}
An experience theory is required if the education is to be wisely carried out (John Dewey). Education is a discipline that saves lives if it is qualified, but loss of which could not be made up throughout generations if it is not qualified. The roots of society are based on the education, and educated masses and civilizations could either move into the future or could fall behind in the race of becoming civilized. The classical education notion which stays on the level of theory and is carried out, centering the teacher is being left by the developed countries and replaced with the education notion which centers the student and structures information by benefiting from experiences, thus aims to lead civilization race with citizens knowing the ways to reach the information and aware of their duties and responsibilities. While Kurt Lewin says nothing is as practical as a good theory, he also catches attention to the new education notion centering student that has changed and is changing. In this scope, the aim of this study is analyze how often active learning methods are used by history teachers through several variables. In the light of the data, after analysis results and explanations made in accordance with these results are written, the study is concluded with suggestions
\end{abstract}

Keywords: education, active learning, history teachers, discussion, thinking skills

\section{Introduction}

Societies are going through a period of social, economic, technological and political change that is called globalization and is said turn the whole word into a small village. The spoken period is processing too fast and changing the quality of individuals and international relations. In order to keep up with the globalization, it is must to develop new notions. In that sense, one of the actors that help societies has concrete and positive results will be the modern education regulations. In today's world, where the technological developments unceasingly break fresh ground, the advancements in the transportation tools, pushing the limits of the mind, close the distances fast, information technologies make it possible to reach unapproachable areas with a single click, and consequently reaching the information is easier than ever, the traditional education practices have come to the point not to be able to meet the needs of the modern world. The change makes it a must to use new teaching methods in the educational sciences. In that process, that the learner constructs knowledge efficiently in terms of the relation between the subject and the object, a principle of modern education notion, is becoming prominent beyond superficial knowledge acquisition, which is a part of traditional education notion.

The relation between learning and teaching and student and teacher takes shape through a pedagogical approach. This approach underlines the importance that students take an active role to create the knowledge, instead of learning it passively. According to the traditional education approach, the teacher collects the knowledge and transfers it to the student. According to the modern education approach, however, by making daily events real-life problems, the teacher guides student to improve their problem solving skills by thinking analytical and creatively and therefore makes learning easier (Wright, Pearson, \& Lloyd, 2007). According to the spoken approach under the umbrella of the cognitive approach, student is no longer passive and becoming active and also taking his/her part in the process as the one who does not memorize the knowledge but construct it. Students who take active roles get rid of their responsibilities of the behavioral approach and take their new responsibilities in the process of active learning. 
As writers of different areas interpret several words in different ways, it is not possible to make a definition of active learning that can be accepted universally. Surprisingly, the way educators use the term of "active learning" is more based on intuitional understanding than a common definition. In addition to this, it is possible to emphasize on the differences about how much universal some definitions and terms that are generally accepted. Active learning is generally defined as any kind of teaching method that guides students during the process of learning. In short, active learning requires students to carry out meaningful learning activities and think about what they do. Yet, many academicians claim that the whole learning is naturally active and that students actively participate in the class while listening to official presentations. However, the analysis of the study literature shows that students ought to do more than mere listening. They should read, write, discuss or try to solve problems. Most importantly, in order for students to participate in the active learning, they should take on the high level tasks of thinking such as analysis, syntheses and evaluation. Most significantly, they should improve their high level thinking skills such as analysis, syntheses and evaluation so that they could participate in active learning (Bonwell \& Eison, 1991).

Active learning means the activities introduced in the class. The main elements of it are student's activeness and participation during the process of learning. Active learning is generally compared to the traditional class in which students passively get knowledge from the educators (Prince, 2004). Many educators accept that the ideal learning experience comes from the classes in which students are prepared to actively construct knowledge and get in the process of learning, instead of taking knowledge passively, and the teachers who teach those classes. This approach is generally called "active learning" (Cook \& Babon, 2016; Gibbs, 1992). Even if the active learning does not have a universal definition, Scheyvens et al. (2008) make the best definition of the active learning by saying what it is not: students passively listen to the speech given by the instructor. Those who support active learning claim that active learning methods could contribute to the development of high level thinking skills in students. And this will encourage a "deeper" approach that forms a basis for students to learn and to make some meaning of the knowledge (Bonwell \& Eison, 1991; Gibbs, 1992; Hanson \& Moser, 2003; Scheyvens et al., 2008).

Bonwell and Eison (1991, p. 19), have listed the various features of active learning:

- Students do more than listening;

- The transition of the knowledge and the development of the students' skills are less emphasized;

- Students start thinking in high level (in other words analysis, syntheses and evaluation);

- $\quad$ Students take part in activities (ex. Reading, discussion and writing);

- More importance should be put on students to discover their own attitudes and values.

In real, students, instead of learning via classes, learn beforehand and they revise, analyze and examine what they learn through the interaction with other students and instructors (Cook \& Babon, 2016). But, especially the big and telling-based classes could pose a hindrance to encourage active learning for both educators and students (Buckley, Bain, Luginbuhl, \& Dyer, 2004; Klein, 2003). Literature underlines the importance of the fact that students should be able to discuss the learning process through such technics as discussion, problem solving, presentations, group working and role playing and that this process should be inter-active as much as possible so that they could take part in it (Gibbs, 1992; Revell \& Wainwright, 2009). Additionally, students should be prepared with the required information and confident to be able to participate in group discussions about the basic concepts while coming to the class. It has been notified by the academicians that preparations works like reading the texts before the class increase the capacity and the confident of the students to participate in the class (Revell \& Wainwright, 2009; Scheyvens et al., 2008; Williams, 1992).

Collaborator learning might refer to any kind of teaching method in which students work as small groups towards a single and common aim (Millis \& Cottel, 1998). Therefore, it could be viewed that the collaborator learning contains all teaching methods that are group-based, including cooperative learning (Millis \& Cottell, 1998; Felder, Brent, \& Stice, 2002). However, some writers divide collaborator learning from cooperative learning due to the fact that they are based on different historical developments and philosophical roots (Bruffee, 1995). In both interpretations, the main element of the cooperative learning is the emphasis on the student interaction, instead of seeing learning as a single activity (Prince, 2004).

Cooperative learning could be defined as a structured group work in which students follow their common goals while they are evaluated individually (Millis \& Cottell, 1997; Feden \& Vogel, 2003). While there are different cooperative learning models existing (Slavin, 1983; Stahl, 1994), the common view is that the focus should be on cooperation, instead of competition, to encourage learning (Prince, 2004). 
Active learning has recently been catching much more attention. Generally, it has been presented or perceived as a radical change to the traditional learning and has been discussed within poles. Active learning has attracted strong supporters from the instructors among which there are ones looking for alternatives to the traditional education methods. However, skeptical instructors perceive it as another actor in a long line of educational orientations (Ptrince, 2004).

Prince (2004) approached to the topic within engineering, and mentioned about questions for many instructors about what the active learning is and how much it is different from traditional engineering education. He underlined that the engineering teaching is already an "active" one due to the assignments and laboratories. In addition to the confusions, he defended how the common forms of active learning and engineering faculty are different from one another and most of the engineering faculties do not tend to research the educational literature for the answers.

On the other hand, Gal, Islam, and Ghahramani (2017) and Cohn, Ghahramani, and Jordan (1986) expressed that active learning had positive results in the field of mechanical engineering. They drew attention to the fact that one of the biggest problems in mechanical operations is to obtain labelled data and this could be a long, tiring and expensive process and could cause the distribution of mechanical learning systems to be non-affordable. While defending that a system learns from little data and a frame in which user can himself choose which knowledge to be labelled would be a frame which could operate mechanical learning more broadly, they added that such frames in the field of education are called active learning. Again, while Gonen, Sabato, and Shalev-Shwartz (2013), Zuluaga, Sergent, Krause, and Püscheş (2013), Du et al. (2017), who question the place of active learning in mechanical engineering teaching, expressed that active learning is a repetitive sampling \& labelling procedure and in each repetition, a sample is chosen for hand-labelling and this is expected to increase the performance of the assortative, approved the activity of active learning from a different perspective.

Another study by Streveler and Menekse (2017), which approaches to the subject from engineering perspective, starts with questioning the risk of asking whether active learning is beneficial or not and shows that they carry two concerns within that scope. According to the authors, this question is not answered clearly. In real, the meta-analysis done by Freeman, Eddy, McDonough, Smith, Okoroafor, Jordth, and Wenderoth (2014) concluded that the active students averagely learn more than the passive ones. The significance of this difference matched up with the findings of the study conducted by Springer, Stanne \& Donovan (1999). Prince (2004) underlined that active learning does not cause statistically a significant difference, but there are generally positive views about active learning in the literary review in which he put forward the roles of the activity-based learning and passive learning methods for the engineering education. These consistent results make us sure that active learning methods make learning attractive for students and therefore there emerges a positive increase in learning (Streveler \& Menekse, 2017).

Including the reports of National Research Council (Bransford, Brown \& Cocking 2000), American Psychology Association (1997) and many other academicians (Baxter-Magolda, 1999; Boyatzis, Cowen \& Kolb 1995; Keeton, Sheckley \& Griggs 2002; Light, 2001; Mentkowski and Associates, 2000; Zull 2002), the attempts to improve higher education concentrate on improvement of the process of learning in education by operating the research called "the new science of research" (Branford et al., 2000). Some of those researches focus on the notion of experiential learning. Experiential learning is mis-taught to students as the tools and methods to gain the experiences that they could learn. However, the experiential learning is more than anything an education philosophy based on the thing Dewey (1938) called as "experience theory". According to Dewey (1938), the traditional education was defined by the practical tradition; it did not need the theory very much. But, the new experiential the approach to education needed a solid experience of practice to lead the action. In this paper, we examine the experiential learning theory (Kolb, 1984) and related studies, and how this knowledge could be used to increase the learning in higher education (Kolb \& Kolb, 2005).

\section{Method}

\subsection{Aim of the Study}

The aim of this study is to evaluate the active learning methods and technics used by history teachers in classes in terms of various reliables (sex, abroad experience, work experience and participation in conferences).

\subsection{Participants of the Study}

This study was conducted with history teachers working in the towns called Erzurum, Sivas, Ağrı, Gaziantep and Tokay in 2014-2015 school year fall and spring semesters. The total participants are 123. 79 of the participants $(64.2 \%)$ are men, 44 ones $(35.5 \%)$ are women. 103 of the participants $(83.7 \%)$ have bachelor's degree, 20 ones 
$(16.3 \%)$ have master's degree. 80 ones of the participants $(65 \%)$ are history graduates, 43 ones $(35 \%)$ are history teaching graduates. 4 of the participants $(3.3 \%)$ have abroad experiences, while 119 one $(96.7 \%)$ have never been to abroad. In terms of professional seniority, 20 ones (16.3\%) are $0-1$ year, 51 ones $(41.5 \%)$ are in $1-5$ years, 20 ones $(16.3 \%)$ are in 6-10 years, 12 ones $(9.8 \%)$ are in $11-15$ years, 8 ones $(6.3 \%)$ are in $21-25$ years and 12 ones (9.8\%) are in 26-30 years. 16 of the participants consisted of trainee teachers $(13.00 \%), 87$ of them are regular teachers $(70.7 \%)$ and 20 ones consisted of administrators (16.3\%). 40 of the participants work in the districts $(32,5 \%)$, and 83 ones work in the city centers $(67.5) \%$. When it comes to the educational events such as seminars and workshops that participants take part in to improve themselves, while 71 of them have participated $(57.7 \%), 52$ ones have never done so $(42.3 \%)$.

\subsection{The Research Design}

In this study, relational screening model that is one of the quantitative research techniques was used. Relational screening models are research models that aim to define the existence of covariance between two or more variables and its level (M. Gall, J. Gall, \& Borg, 2014). In descriptive analysis, what events, objects, beings and institutions and various areas are (Kaptan, 1991) are tried to be explained with descriptive statistics like frequencies, percentage, average and standard deviation.

\subsection{Data Collection Tools}

The data of the study was obtained by usinf the "Survey of Active Learning Methods and Technics" prepared by the researcher. Before scale form was operated on the study group, validity and reliability works were done and Cronbach Alpha Reliability Index was calculated as 0.83 . The survey consists of 73 articles that are about active learning methods and technics level of knowledge. The scale that was prepared in fivefold likert scale was operated as "I don't know at all, I know little, I know but I never used, I know and I sometimes use, I know and I most of the time use". Participants gave points to this fivefold likert type survey, ranging from 1 to 5.

\subsection{Data Analysis}

The data analysis was evaluated with One Way ANOVA and Post Hoc Turkey Test methods by using SPSS 18.00 package program. Also, correlation analyses were made for frequencies and percentage calculations. As the articles 21 th and 23th were not commented by the participants at all, there emerged no value. The values like variance and average about active learning methods and technics are presented in no. 1.

\section{Findings and Comments}

In this section, independent $t$ test analyzes of teachers' use of active learning methods and techniques according to gender, foreign country experience and participation in seminars related to professional experience; according to the position of the place where he worked, according to the division in which he graduated, the year of his seniority, the status at the school where he was employed Anova test analysis is conducted. Independent $t$ test analysis results are given in Table 1 according to gender differences.

Table 1. Independent $t$ test results according to gender differences

\begin{tabular}{lccccccc}
\hline Gender & $\mathrm{n}$ & average & $\mathrm{sh}$ & $\mathrm{F}$ & $\mathrm{t}$ & $\mathrm{df}$ & $\mathrm{p}$ \\
\hline Man & 79 & 208.8734 & 5.79580 & .259 & -1.065 & 121 & .289 \\
\hline Woman & 44 & 215.0455 & 5.37311 & & -1.149 & 109.387 & .253 \\
\hline
\end{tabular}

As it is seen in Table 1, there is no significant difference between teachers' gender differences ( $p>0.05)$. Independent $t$ test analysis results according to foreign country experience are given in Table.

Table 2. Independent $t$ test analysis results according to foreign country experience

\begin{tabular}{cccccccc}
\hline Having experience of going abroad & $\mathrm{n}$ & average & $\mathrm{sh}$ & $\mathrm{F}$ & $\mathrm{t}$ & $\mathrm{df}$ & $\mathrm{p}$ \\
\hline yes & 4 & 239.0000 & 2.83324 & 6.175 & 1.860 & 121 & .000 \\
\hline no & 119 & 210.1429 & & & 10.185 & 118.000 & \\
\hline
\end{tabular}

As it is seen in Table 2, there is a significant difference $(p<0.05)$ in favor of teachers with foreign experience according to the results of the independent $t$ test according to the experiences of the teachers abroad. Accordingly, it is seen that teachers who have experience going abroad use more active learning techniques and methods. Table 3 gives the results of independent $t$ test analysis according to participation in seminars related to 
professional experience.

Table 3. The results of independent $t$ test analysis according to participation in seminars related to professional experience

\begin{tabular}{cccccccc}
\hline Participation in seminars & $\mathrm{n}$ & $\mathrm{x}$ & $\mathrm{sh}$ & $\mathrm{F}$ & $\mathrm{t}$ & $\mathrm{df}$ & $\mathrm{p}$ \\
\hline Yes & 71 & 202.5493 & 3.20178 & 8.174 & -3.777 & 121 & .000 \\
\hline No & 52 & 222.7308 & 4.46058 & & -3.676 & 98.116 & \\
\hline
\end{tabular}

As it is seen in Table 3, independent $t$ test results according to participation in seminars, workshops and training programs related to professional experiences reveals significant results in favor of teachers who did not participate in these studies $(p<0.05)$. Teachers who did not participate in the seminars are more likely to use active learning techniques and methods. In this case, the result is that the seminars are not done in a proper way for the purpose. The analysis results of Anova test according to the department that the teacher graduated in table 4 are given.

Table 4. Anova test according to the department that the teacher graduated

\begin{tabular}{ccccccccc}
\hline Department & $\mathrm{N}$ & average & $\mathrm{sd}$ & sh & Ki-kare & df & $\mathrm{f}$ & $\mathrm{p}$ \\
\hline History & 80 & 208.8250 & 28.30743 & 3.16487 & & 1 & 1.228 & 0.270 \\
\hline History Teaching & 43 & 215.2791 & 35.00770 & 5.33862 & & 121 & \\
\hline Total & 123 & 211.0813 & 30.82755 & 2.77963 & & 122 \\
\hline Between Groups & & \multicolumn{7}{c}{1164.986} \\
\hline In Groups & & \multicolumn{7}{c}{114776.201} \\
\hline Total & & & \multicolumn{7}{c}{115941.187} \\
\hline
\end{tabular}

As it is shown in Table 4, in terms of the departments where the teachers graduated no significant difference is found according to the results of Anova test ( $>>0.05$ ). It is seen that the teachers' use of the active learning methods and techniques are not affected by the departments they graduated. Table 5 shows the results of the Anova test analysis according to the seniority year in the profession.

Table 5. The results of the Anova test analysis according to the seniority year in the profession

\begin{tabular}{|c|c|c|c|c|c|c|c|c|}
\hline the seniority year in the profession & $\mathrm{N}$ & average & $\mathrm{sd}$ & sh & kikare & $\mathrm{df}$ & $\mathrm{f}$ & $\mathrm{p}$ \\
\hline 0-1 Year & 20 & 253.8000 & 16.76337 & 3.74840 & & 5 & 15.739 & .000 \\
\hline 1- 5 Years & 51 & 205.3137 & 23.32423 & 3.26605 & & 117 & & \\
\hline $6-10$ Years & 20 & 206.6000 & 18.23357 & 4.07715 & & 122 & & \\
\hline $11-15$ Years & 12 & 202.6667 & 21.78128 & 6.28771 & & & & \\
\hline 21-25 Years & 8 & 187.5000 & 59.33200 & 20.97703 & & & & \\
\hline 26-30 Years & 12 & 196.0000 & 7.38549 & 2.13201 & & & & \\
\hline Total & 123 & 211.0813 & 30.82755 & 2.77963 & & & & \\
\hline Between Groups & & & & & 46623.540 & & & \\
\hline In Groups & & & & & 69317.647 & & & \\
\hline Total & & & & & 115941.187 & & & \\
\hline
\end{tabular}

As it is seen in Table 5, according to the results of the Anova test in terms of the seniority of the profession, it is found that it is significant for the teachers between $0-1$ years in the profession $(p<0.05)$. According to this, it is seen that teachers who are between $0-1$ in profession use active learning methods and techniques more. Teachers with more seniority in the profession have seen less use of these methods and techniques. Table 6 gives the results of Anova test analyzes according to their positions in the school where they are working. 
Table 6. Anova test analysis according to their positions in the school where they are working

\begin{tabular}{|c|c|c|c|c|c|c|c|c|}
\hline Their positions in the school & $\mathrm{N}$ & average & $\mathrm{sd}$ & $\mathrm{sh}$ & Ki-kare & $\mathrm{df}$ & $\mathrm{F}$ & $\mathrm{p}$ \\
\hline Intern & 16 & 232.5000 & 33.59762 & 8.39940 & & 2 & 6.944 & .001 \\
\hline Principal Teacher & 87 & 210.6552 & 26.72418 & 2.86513 & & 120 & & \\
\hline Administrator & 20 & 195.8000 & 36.68013 & 8.20193 & & 122 & & \\
\hline Total & 123 & 211.0813 & 30.82755 & 2.77963 & & & & \\
\hline Between Groups & & & & & 12026.332 & & & \\
\hline In Groups & & & & & 103914.855 & & & \\
\hline Total & & & & & 115941.187 & & & \\
\hline
\end{tabular}

As it is shown in Table 6, the results of the Anova test according to the positions of the teachers in the schools are important for the intern teachers $(\mathrm{p}<0.05)$. It has been understood that teachers who started teaching in schools use more active learning methods and techniques than administrators or principle teachers who work in schools. Among these teachers, it is revealed that administrators use less of these methods and techniques. According to the position of the place in Table 7, Anova test is given to the analysis results.

Table 7. Anova test results according to the position of the place where they work

\begin{tabular}{|c|c|c|c|c|c|c|c|c|}
\hline Geographical Position & $\mathrm{N}$ & ortalama & sd & sh & Ki-kare & df & $\mathrm{f}$ & $\mathrm{p}$ \\
\hline Province & 40 & 236.4500 & 29.76054 & 4.70555 & & 1 & 59.338 & .000 \\
\hline City & 83 & 198.8554 & 22.96611 & 2.52086 & & 121 & & \\
\hline Total & 123 & 211.0813 & 30.82755 & 2.77963 & & 122 & & \\
\hline Between Groups & & & & & 38149.022 & & & \\
\hline In Groups & & & & & 77792.165 & & & \\
\hline Total & & & & & 115941.187 & & & \\
\hline
\end{tabular}

As shown in Table 7, the results of the Anova test based on the geographical location of the teachers' working place are significant in favor of teachers in the province $(\mathrm{p}<0.05)$. According to the teachers in the province, they are using more active learning methods and techniques.

\section{Conclusion and Suggestions}

The data shows that there is no statistically meaningful difference between sex and active learning. Erdem, Uzal, and Ersoy (2006, also concluded that there is no difference between science and physics teachers' level of teaching methods use and their sexes in the study they conducted nationwide. And Narin and Aybek (2010) reported that social studies teachers' choice of teaching methods do not show a meaningful difference statistically in terms of sexes, teaching methods choices do not change because of sexes. According to the researchers, considering that analytical thinking skills do not change due to sexes, it could be an expected result that teaching methods used by teachers who have high capacity of analytical thinking are the methods that make students active, reach the conclusion on their own, learn by living, ask, question and those that aim to raise individuals who are open to discuss different ideas. On the other hand, Tokdemir (2013), who has researched about history teachers' ideas and methods about the use of discussion method for teaching secondary education history class, has reported that while history teachers' ideas about the use of discussion change due to the type of school, professional seniority and their sexes, it is observed that the type of school from which they graduated do not have an effect, which could not be said to be meaningful, on the use of discussion method in history classes. Lastly Uzal, Erdem and Ersoy (2016), could not find any meaningful difference between maths/sciences (science and technology) teachers' sexes and their ideas about in-class teaching methods.

The findings of the study show that teachers with abroad experience use active learning methods and technics more often. It could be said that the teachers who spent some time especially in the Western countries, whose education system is improved, saw the right examples about the enough use of methods and technics in question by living is effective on this result. Studies show that constructed operations are the most frequently referred teaching methods in other countries. The most significant difference between Turkey and international averages is that small group works and the check of assignments are less often referred in Turkey (Martin, Mullis, \& Foy, 2009; OECD, 2009; Uzal et al., 2016).

It was observed that the teachers who do not attend in-service education seminars are more often to use active 
learning technics and methods. Thus, it becomes clear that seminars are not organized in the way that is not suitable for their purposes. Narin and Aybek (2010) also concluded that the teaching methods social studies teachers prefer do not change in accordance with whether taking in-service education seminar or not. In the study, in which it is expressed that the reason for this is that in-service education seminars are not organized suitable for their purpose, the teachers have commented that in-service education services are organized in a limited amount of time, as big crowded groups and mostly not given by individuals who are experts in their fields. In that sense, it has been assumed that either the teachers do not benefit enough from in-service education seminars or in-service education seminars could not fill their purpose (Narin \& Aybek, 2010).

In the light of findings of the study, the history teachers expressed that among active learning methods and technics, while they most frequently use "problem solving" (avg. 3.9), "examining sample event" (avg. 3.9), "brain storming" (avg. 3.8), "developing project" (3.7) and "thinking otherwise" (avg. 3.7), those they less frequently use are "find the treasure" (avg. 1.9), "snowball" (1,9) and "jigsaw" (avg. 1.7). Question-answer technic, which is one of the traditional teaching methods and technics, is in the middle with 2.2 average. V. Aktepe and L. Aktepe (2009) found that telling is the most frequently used method in science and technology teaching. The second and the third methods are experimenting in either laboratory or in classroom. While student is passive for telling, $\mathrm{s} / \mathrm{he}$ is active for the experiment. The students want the discussion method, but its ratio is so low. Question-answer, "tour" outside of class or school and "observation", project and problem solving methods are occasionally used, but drama is never used (V. Aktepe \& L. Aktepe, 2009). Çelikkaya and Kuş (2009) put forward that while social studies generally teachers use technics and methods like discussion, question-answer, brain storming, presentation, project all the time, they use technics and methods such as benefiting from the source person, tour-observation, telling and drama quite less often. Öztürk (2004) has expressed that geography teachers keep on using classical teaching methods, but they "never" use the method of tour-observation, which is one of the irreplaceable elements for geography teaching. According to the author, teachers has expressed that question-answer method is mostly used, while the students has expressed it is only mere telling method. Whereas teachers said the less frequently used method is the project, the students made it clear that it is tour-observation method that they less frequently encounter. Şimşek, Hırça, and Coşkun (2012) have expressed that the active learning methods science and technology teachers most frequently use are "question-answer, telling and problem solving" (telling is not actually an active learning method), and the methods they less frequently use are "tour-observation and project developing". Y1ldirım (2011) concluded that science and technology and math teachers use the teaching methods in which students are passive in almost every single class. On the other hand, Yildirım discovered that the constructed, practical classes in which student are active occurs between $25 \%$ and $50 \%$. The number of the studies which claim that project developing method is not paid enough attention by the teachers is quite high (Aydede, Çağlayan, Matyar, \& Gülnaz, 2006; Duban \& Küçükyılmaz, 2008; Aktepe \& Aktepe, 2009; Güneş, Dilek, Hoplan, Çelikoğlu, \& Demir, 2010; Geçer \& Özel, 2012; Güneş, Dilek, Çelikoğlu, \& Demir, 2012; Uzal et al., 2016).

The discussion, one of the important active learning methods, could not be used in the classes very often due to both lack of capacity and the concerns caused by it. The average of 2,7 ratio also contributes to this scene. In literature, there are researches which defend the idea that because of both the sensitiveness of the topic (Akman, 2016; Byford, Lennon, \& Russel, 2009; Demircioğlu, 2016; Hess, 2004; Kaya, Güven, \& Günal, 2013; Philpott, Clabough, McConey, \& Turner, 2011; Reitano, Kivunja, \& Porter, 2008; Seng \& Jaffar, 2014; Stradling, Noctor, \& Baines, 1984; Waliaula, 2011; Zembylas \& Kambani, 2012) and that it is a method that is time consuming and requires being prepared (Dean \& Joldoshaieva, 2007; Dube, 2015; McKernan, 1982; Merryfield, 1993; Oulton, Day, Dillon, \& Marcus, 2004; Waliaula, 2011), social studies teachers do not include this method in classes very much while teaching controversial topics.

The departments from which the teachers have graduated do not affect the active learning methods and technics they use. In other words, no relation between the teaching methods history teachers prefer and the higher education institution from which they have graduated could be found. Therefore, it could be said that the higher education institutions from which the teachers have graduated do not affect the teaching methods they prefer. But, Erdem et al. (2006) put forward that science and physics teachers' level of use of teaching methods could change in accordance with the education institutions from which they have graduated.

It was observed that teachers who have work a year or less work experiences tend to use active teaching methods and technics more, and those who have high professional seniority tend to use them less. It was understood that in schools, the teachers who just started their profession use the active learning methods and technics much more, in comparison to the administrators or regulars teachers working in school. Besides, Şimşek, Hırça, and Coşkun (2012), has caught attention to the fact that the science and technology teachers who just started their careers are 
more willing to use active learning methods and technics more, and explained that the reason why is they are more idealist. According to the study, the more they gain experience, the less idealist they become (Şimşek, Hırça, \& Coşkun, 2012). Erdem et al. (2006) concluded that the teachers' level of use of teaching methods differentiates in accordance with professional seniority, but it does not change in terms of the type of school in which they work. However, it is also known that in recent years, Education Faculties have been organizing their education programs according to the constructive approach and it is recommended that classes be based on teacher candidates and be taught in parallel with new approach and developments and this view is placed in the operations. But, the level of the fact that these suggestions and expectations take place is yet low and change and improvement should be provided. It could be foreseen that teachers that have been working in school for so long and have not had the opportunity and chance to refresh themselves have more needs and lacks in the spoken subject (Uzal et al., 2016). Narin and Aybek (2010), who has reached conclusion opposing to the finding, have determined that there is a difference in favor of those who have higher professional seniority in the relation between teachers' professional seniority and the active learning methods they choose to use.

That the teachers are not good enough at using different teaching methods together could be resulted from lack of information about method features, lack of understanding of the importance of using them together and lack of experience in these areas. Besides, the concern to finish off the class in time might be effective on this. For, using different methods could require more time. Yeşil (2006) notified significant inadequacies at using methods in the study Yeşil conducted on the teaching quality of social studies teachers. According to Özkal, Güngör, and Çetingöz (2004), one of the important reasons why students do not choose social studies is the teaching methods that are used. Doğan (2004) notified that the methods that teachers mostly prefer are question-answer, telling and discussion. Apart from that, Emiroğlu (2002) concluded that T.R revolution history and kemalism class teachers could not move beyond the classical choices when it comes to the use and choosing of teaching methods in the study conducted by Emiroğlu. And the mentioned classical methods are knowledge-based and do not require material use (Yeşil, 2009).

The data shows that history teachers give place to computer aided teaching technics in their classes (avg. 3.6). Yet, according to the data of international research, computer and educational technologies are not very much used in Turkey. According to $58,8 \%$ of the students, computer and educational technologies are rarely used (Ylldırım, 2011). According to the national data, however, the situation in our country is much more optimistic (Uzal et al., 2016). Nevertheless, teachers could not make students participate actively in teaching activities in classes/lessons (Yıldırım, 2011; Uzal et al., 2016).

One of the requirements for teachers to use active learning methods and technics efficiently is to develop skills of critical-creative thinking and problem solving. For, the teachers who could improve these skills will also prefer the teaching methods that aim to improve these skills more. In other words, since critical thinking require to question, research, and think scientifically, the methods the teachers with high level of capacity to think critically prefer to use for teaching classes will also be active learning methods.

That some of the public funding is spared in order for teachers to gain abroad experience will also have a positive effect on teachers' use of active learning methods and technics in their classes. Especially, a research trip organized for the countries that have well developed education system will contribute a lot to teachers.

It is a surprising and saddening result that the teachers that do not attend in-service education seminars use active learning methods and technics more efficiently. The purpose of the seminars in question should be to tell the recent innovations and developments in education to teachers. It could be claimed that a seminar understanding that does not teach active learning.

When the literature is examine, it is observed that teacher-based teaching method is not very common, it is not left out altogether, yet. When Einstein said "I do not teach my students, I teach them how to learn, he pointed out the inadequacies of classical education approach and what is important is that student learn by himself/herself. In order to do that, the teacher candidates should graduate, acquiring the reading habit and embracing the discussion culture. The idealism of the newly graduate teachers is very much important, even essential for this matter. It will play an essential role to create an education army full of qualified teachers that are ready to improve themselves and constantly refresh themselves in order to endure the struggles of teaching occupation and to have inner satisfaction. Therefore, it will play the most significant and essential role for the teachers that both increase the quality of their classes and, by centering students, raise qualified individuals with citizenship consciousness and responsibility that construct knowledge according to their own experiences by using different active learning methods and technics together. 


\section{References}

Akman, Ö. (2016). Status of the Usage of Active Learning and Teaching Method and Techniques by Social Studies Teachers. Universal Journal of Educational Research, 4(7), 1553-1562. https://doi.org/10.13189/ujer.2016.040708

Aktepe,V., \& Aktepe, L. (2009). Fen ve teknoloji öğretiminde kullanılan öğretim yöntemlerine ilişkin öğrenci görüşleri: Kırşehir BİLSEM örneği. Ahi Evran Üniversitesi Kırşsehir Eğitim Fakültesi Dergisi, 1(10), 69-80.

American Psychological Association Board of Affairs. (1997). Learner-centered psychological principles: A framework for school redesign and reform. Retrieved from http://www.apa.org/ed/lcp.html

Aydede, M. N., Çağlayan, Ç., Matyar, F., \& Gülnaz, O. (2006). Fen ve teknoloji öğretmenlerinin kullandıkları öğretim yöntem ve tekniklerine ilişkin görüşlerinin değerlendirilmesi. ÇÜ Eğitim Fakültesi Dergisi, 3(32), 24-33.

Baxter-Magolda, M. B. (1999). Creating contexts for learning and self-authorship. Nashville, TN: Vanderbilt University Press.

Bonwell, C. C., \& Eison, J. A. (1991). Active Learning: Creating Excitement in the Classroom. 1991 ASHE-ERIC Higher Education Reports. ERIC Clearinghouse on Higher Education, The George Washington University, One Dupont Circle, Suite 630, Washington, DC 20036-1183.

Boyatzis, R. E., Cowen, S. S., \& Kolb, D. A. (1995). Innovation in professional education: Steps on a journey from teaching to learning. San Francisco: Jossey-Bass.

Bransford, J. D., Brown, A. L, \& Cocking, R. R. (2000). How people learn: Brain, mind experience, and school. Washington DC: National Academy Press.

Bruffee, K. A. (1995). Sharing our toys: Cooperative learning versus collaborative learning._Change: The Magazine of Higher Learning, 27(1), 12-18. https://doi.org/10.1080/00091383.1995.9937722

Buckley, G. L., Bain, N. R., Luginbuhl, A. M., \& Dyer, M. L. (2004). Adding an "active learning" component to a large lecture course. Journal of Geography, 103(6), 231-237. https://doi.org/10.1080/00221340408978607

Byford, J., Lennon, S., \& Russel, W. B. (2009). Teaching controversial issues in the social studies: a research study of high school teachers. The Clearing House: A Journal of Educational Strategies, Issues and Ideas, 82(4), 165-170. https://doi.org/10.3200/TCHS.82.4.165-170

Çelikkaya, T., \& Kuş, Z. (2009). Sosyal bilgiler öğretmenlerinin kullandıkları yöntem ve teknikler. Uludă̆ Üniversitesi Ĕ̈itim Fakültesi Dergisi, 22(2), 741-758.

Cohn, D. A., Ghahramani, Z., \& Jordan, M. I. (1986). Active learning with statistical models. Journal of artificial intelligence research, 4, 129-145.

Cook, B. R., \& Babon, A. (2016). Active learning through online quizzes: better learning and less (busy) work. Journal of Geography in Higher Education, 41(1), 24-38. https://doi.org/10.1080/03098265.2016.1185772

Dean, B., \& Joldoshaieva, R. (2007). Key strategies for teachers new to controversial issues. In H. Claire, \& C. Holden (Eds), The Challenge of Teaching Controversial Issues (pp. 175-187). Trentham Books Limited: USA.

Demircioğlu, İ. H. (2016). Tarih derslerinde tartışmalı konuların kullanımı: Türk tarih öğretmenlerinin görüşleri. Kastamonu Eğitim Dergisi, 24(1), 147-162.

Dewey, J. (1938). Education and experience. New York: Simon and Schuster.

Doğan, C. (2004). Sınıf öğretmenlerinin derslere ilişkin görüşleri ve tercih ettikleri öğretim yöntemleri. Türk Eğitim Bilimleri Dergisi, 2(2), 193-203.

Du, B., Wang, Z., Zhang, L., Zhang, L., Liu, W., Shen, J., \& Tao, D. (2017). Exploring representativeness and informativeness for active learning. IEEE transactions on cybernetics, 47(1), 14-26. https://doi.org/10.1109/TCYB.2015.2496974

Duban, N., \& Küçükyılmaz, E. A. (2008). Primary education pre-service teacher's opinions regarding to the use of alternative measurement-evalution methods and techniques in practice schools. Elemantary Education Online, 7(3), 769-784.

Dube, O. (2009). Addressing current controversial issues through the social studies curriculum: making social studies come alive. European Journal of Educational Studies, 1(1), 25-34. 
Erdem,A., Uzal, G., \& Ersoy, Y., (2006). Fen Bilgisi/Fizik Öğretmenlerinin Eğitim Sorunlarl: Gelişmeleri Sürekli İzlemeleri ve Gerekli Yenilikleri Edinmeleri (Araştırma Raporu). TFV Yayını, Tekirdağ.

Feden, P. D., \& Vogel, R. M. (2003). Methods of teaching: Applying cognitive science to promote student learning. McGraw-Hill Humanities, Social Sciences \& World Languages.

Felder, R., Brent, R., \& Stice, J. (2002). National Effective Teaching Institute: Workshop Materials. In 2002 American Society for Engineering Education Annual Conference, Montreal, Quebec, Canada.

Freeman, S., Eddy, S. L., McDonough, M., Smith, M. K., Okoroafor, N., Jordt, H., \& Wenderoth, M. P. (2014). Active learning increases student performance in science, engineering, and mathematics. Proceedings of the National Academy of Sciences, 111(23), 8319-8320. https://doi.org/10.1073/pnas.1319030111

Gal, Y., Islam, R., \& Ghahramani, Z. (2017). Deep Bayesian Active Learning with Image Data. arXiv preprint arXiv:1703.02910.

Gall, M. D., Gall, J. P., \& Borg, W. R. (2014). Applying educational research: How to read, do, and use research to solve problems of practice. Pearson Higher Ed.

Geçer, A., \& Özel, R. (2012). İlköğretim fen ve teknoloji dersi öğretmenlerinin öğrenmeöğretme sürecinde yaşadıkları sorunlar (English). Educational Sciences: Theory \& Practice, 12(3), 2237-2255.

Gibbs, G. (1992). Improving the quality of student learning: Based on the Improving Student Learning Project funded by the Council for National Academic Awards. Technical and Education Services.

Gonen, A., Sabato, S., \& Shalev-Shwartz, S. (2013). Efficient active learning of halfspaces: An aggressive approach. The Journal of Machine Learning Research, 14(1), 2583-2615.

Günal, H., \& Kaya, R. (2016). Tarih Öğretmenlerinin Tartışmalı ve Hassas Konuların Öğretimi Sırasında Yaşadıkları Çekince ve Sorunlar (Erzurum Örneği). Türk Tarih Eğitimi Dergisi, 5(1), 44-73.

Güneş,T., Dilek, N. Ş., Çelikoğlu, M., \& Demir, E. S. (2012). The using of the teaching methods and techniques by science and technology teachers and class teachers. Cypriot Journal of Educational Sciences, 7(2), 82-91.

Güneş,T., Dilek, N. Ş., Hoplan, M., Çelikoğlu, \& Demir, E. S. (2010). Öğretmenlerin alternatif değerlendirme konusundaki görüşleri ve yaptıkları uygulamalar. In International Conference on New Trends in Education and Their Implications, 11-13.

Hanson, S., \& Moser, S. (2003). Reflections on a discipline-wide project: Developing active learning modules on the human dimensions of global change. Journal of Geography in Higher Education, 27(1), 17-38. https://doi.org/10.1080/0309826032000062441

Hess, D. (2004). Controversies about controversial issues in democratic education. PS: Political science and politics, 257-261. https://doi.org/10.1017/S1049096504004196

Kaptan, S. (1991). Bilimsel araştırma ve istatistik teknikleri. Gazi Üniversitesi.

Kaya, R., Güven, A., \& Günal, H. (2013). Öğretmenlerin gözüyle çağdaş tarihin öğretimi: Erzurum Örneği. Tarih Okulu Dergisi (TOD), 6(16), 555-587.

Keeton, M. T., Sheckley, B. G., \& Griggs, J. K. (2002). Efficiency and effectiveness in higher education. Dubuque, IA: Kendall/ Hunt Publishing Company.

King, P. M. (2003). Student learning in higher education. In S. R. Komives, D. B. Woodward, Jr., \& Associates (Eds.), Student services: A handbook for the profession (pp. 234-268). San Francisco: Jossey Bass.

Klein, P. (2003). Active learning strategies and assessment in world geography classes. Journal of Geography, 102(4), 146-157. https://doi.org/10.1080/00221340308978539

Kolb, A. Y., \& Kolb, D. A. (2005). Learning styles and learning spaces: Enhancing experiential learning in higher education. Academy of management learning \& education, 4(2), 193-212. https://doi.org/10.5465/AMLE.2005.17268566

Kolb, D. A. (1984). Experiential learning: Experience as the source of learning and development. New Jersey: Prentice-Hall.

Light, R. J. (2001). Making the most of college: Students speak their minds. Cambridge, MA: Harvard University Press.

Martin, M., Mullis, I., \& Foy, P. (2009). TIMSS 2007 international science report. Boston College: TIMSS \& 
PIRLS International Study Center.

McKernan, J. (1982). Constraints on the handling of controversial issues in Northern Ireland post-primary schools. British Educational Research Journal, 8(1), 57-71. https://doi.org/10.1080/0141192820080106

Mentkowski, M., \& Associates. (2000). Learning that lasts: Integrating learning, development and performance in college and beyond. San Francisco, CA: Jossey Bass.

Merryfield, M, M. (1993). Responding to Gulf War: a case study of instructional decision making. Social Education, 57(1), 33-41.

Millis, B. J., \& Cottell Jr, P. G. (1997). Cooperative Learning for Higher Education Faculty. Series on Higher Education. Oryx Press, PO Box 33889, Phoenix, AZ 85067-3889.

Narin, N., \& Aybek, B. (2010). İlköğretim ikinci kademe sosyal bilgiler öğretmenlerinin eleştirel düşünme becerilerinin incelenmesi. Çukurova Üniversitesi Sosyal Bilimler Enstitüsü Dergisi, 19(1), 336-350.

OECD. (2009). Creating effective teaching and learning environments: First results from TALIS. Paris: OECD Pub. https://doi.org/10.1787/9789264068780-en

Oulton, C., Day, V., Dillon, J., \& Marcus, M. M. (2004). Controversial issues-teachers' attitudes and practices in the context of citizenship education, Oxford Review of Education, 30(4), 489-507. https://doi.org/10.1080/0305498042000303973

Özkal, N., Güngör, A., \& Çetingöz, D. (2004). Sosyal bilgiler dersine ilişkin öğretmen görüşleri ve öğrencilerin bu derse yönelik tutumları. Kuramdan Uygulamaya Eğitim Yönetimi Dergisi, 40, 600-615.

Öztürk, Ç. (2004). Ortaöğretim coğrafya öğretmenlerinin öğretim yöntem ve teknikleri kullanabilme yeterlilikleri. Ahi Evran Üniversitesi Kırşehir Eğitim Fakültesi Dergisi, 5(2), 75-83.

Philpott, S., Clabough, J., McConkey, L., \& Turner, T. N. (2011). Controversial issues: to teach or not to teach? That is the question! The Georgia Social Studies Journal, 1(1), 32-44.

Prince, M. (2004). Does active learning work? A review of the research. Journal of engineering education, 93(3), 223-231. https://doi.org/10.1002/j.2168-9830.2004.tb00809.x

Reitano, P., Kivunja, C., \& Porter, K. (2008). Teaching controversial issues in schools to prepare children for a sustainable global village. Paper presented at the Australian Association for Research in Education (AARE) Conference Brisbane, November 30-December 4.

Revell, A., \& Wainwright, E. (2009). What makes lectures 'unmissable'? Insights into teaching excellence and active learning. Journal of Geography in Higher Education, 33(2), 209-223. https://doi.org/10.1080/03098260802276771

Scheyvens, R., Griffin, A. L., Jocoy, C. L., Liu, Y., \& Bradford, M. (2008). Experimenting with active learning in geography: Dispelling the myths that perpetuate resistance. Journal of Geography in Higher Education, 32(1), 51-69. https://doi.org/10.1080/03098260701731496

Seng, L. K., \& Jaffar, J. (2014). Academic controversy and Singapore history: context, teachers and subpublics. In M. Baildon, L. K. Seng, I. M. Lim, G. İnanç, \& J. Jaffar (Eds.), Controversial History Education in Asian Contexts (pp. 165-180). London and New York: Routledge-Taylor \& Francis Group.

Şimşek, H., Hırça, N., \& Coşkun, S. (2012). İlköğretim Fen ve Teknoloji Öğretmenlerinin Öğretim Yöntem ve Tekniklerini Tercih ve Uygulama Düzeyleri: Şanlıurfa ili Örneği. Mustafa Kemal Üniversitesi Sosyal Bilimler Enstitüsü Dergisi, 9(18), 249-268.

Slavin, R., (1983). Cooperative Learning. Research on Teaching Monograph Series. ERIC Digest ED242707.

Springer, L., Stanne, M. E., \& Donovan, S. S. (1999). Effects of small-group learning on undergraduates in science, mathematics, engineering, and technology: A meta-analysis. Review of Education Research, 69, 21-51. https://doi.org/10.3102/00346543069001021

Stahl, R. J. (1994). The Essential Elements of Cooperative Learning in the Classroom. ERIC Digest.

Stradling, R., Noctor, M., \& Baines, B. (1984). An overview. In S. Hill, \& C. C. Reid (Eds.), Teaching Controversial Issues. Great Britain: Edward Arnold. 103-116.

Streveler, R. A., \& Menekse, M. (2017). Taking a Closer Look at Active Learning. Journal of Engineering Education, 106(2), 186-190. https://doi.org/10.1002/jee.20160

Tokdemir, M. A. (2013). Ortaöğretim tarih dersinin öğretiminde tartışma yöntemine iliş̧kin öğretmenlerin görüş 
ve uygulamaları (Ankara ili örneği) (Yayınlanmamış Doktora Tezi). Gazi Üniversitesi, Ankara.

Uzal, G., Erdem, A., \& Ersoy, Y. (2016). Bir grup matematik ve fen bilimleri öğretmeninin sınıf içinde gerçekleştirdikleri öğretim etkinliklerinin incelenmesi. Buca Eğitim Fakültesi Dergisi, 40, 64-85.

Waliaula, A. J. (2011). Teaching local and global controversial issues in the social studies education: a comparative study of Kenyan and US high schools (Unpublished $\mathrm{PhD}$ thesis). University of The Ohio State, Ohio, USA.

Williams, A. M. (1997). Making the most of assigned readings: Some alternative strategies. Journal of Geography in Higher Education, 21(3), 363-371. https://doi.org/10.1080/03098269708725442

Wright, S., Pearson, S. S., \& Lloyd, K. (2007). An Interwoven Learning Exchange: Transforming Research Teaching Relationships in the Top End, Northern Australia, Geographical Research, 45(2), 150-157. https://doi.org/10.1111/j.1745-5871.2007.00444.x

Yeşil, R. (2006). Sosyal bilgiler öğretmenlerinin sınıf içi öğretim yeterlikleri. Ahi Evran Üniversitesi Kırşehir Ĕ̈itim Fakültesi Dergisi, 7(2), 61-78.

Yeşil, R. (2009). Sosyal Bilgiler Aday Öğretmenlerinin Sınıf İçi Öğretim Yeterlilikleri. Türk Eğitim Bilimleri Dergisi, 7(2), 327-352.

Yıldırım, K. (2011). Uluslararası araştırma verilerine göre Türkiye'de ilköğretim fen ve teknoloji derslerindeki öğretim uygulamaları. Türk Fen Eğitimi Dergisi, 8(1), 153-174.

Zembylas, M. and Kambani, F. (2012). The teaching of controversial issues during elementary-level history instruction Greek-Cypriot teachers' perceptions and emotions. Theory \& Research in Social Education, 40, 107-133. https://doi.org/10.1080/00933104.2012.670591

Zull, J. E. (2002). The art of changing the brain: Enriching teaching by exploring the biology of learning. Sterling, VA: Stylus.

Zuluaga, M., Sergent, G., Krause, A., \& Püschel, M. (2013, February). Active learning for multi-objective optimization. In International Conference on Machine Learning, PMLR, 28(1), 462-470.

\section{Appendix 1}

\section{Active Learning Techniques and Methods Variance Values}

\begin{tabular}{|l|c|c|c|c|c|c|c|c|c|}
\hline Methods and technics & $\mathrm{N}$ & Mean & $\mathrm{sd}$ & Variance & Methods and technics & $\mathrm{N}$ & mean & sd & variance \\
\hline Brainstorming & 123 & 3.8699 & .75704 & .573 & Empathy & 123 & 2.3171 & 1.03478 & 1.071 \\
\hline Mind Mapping & 123 & 3.1545 & 1.11644 & 1.246 & Mutual Instruction & 123 & 2.6504 & 1.29301 & 1.672 \\
\hline Concept Network & 123 & 3.0650 & 1.17166 & 1.373 & Through Invention & 123 & 3.7236 & 1.05038 & 1.103 \\
\hline Concept Map & 123 & 3.2846 & 1.09035 & 1.189 & $\begin{array}{c}\text { Finding Cause-Result } \\
\text { Relationship }\end{array}$ & 123 & 3.4634 & 1.04248 & 1.087 \\
\hline Project & 123 & 3.7967 & .96631 & .934 & Yordama Yapma & 123 & 3.5854 & .91371 & .835 \\
\hline Conference & 123 & 2.9024 & .59250 & .351 & Making Prediction & 123 & 3.7154 & 1.14891 & 1.320 \\
\hline Panel & 123 & 3.0000 & .62725 & .393 & Thinking Aloud & 123 & 3.5203 & 1.14053 & 1.301 \\
\hline Open Session & 123 & 3.1626 & .72851 & .531 & $\begin{array}{c}\text { Speaking in Order } \\
\text { (Flash) }\end{array}$ & 123 & 3.0325 & 1.10093 & 1.212 \\
\hline Collegium & 123 & 2.2602 & .84773 & .719 & Teaching Someone & 123 & 3.0325 & .97455 & .950 \\
\hline Forum & 123 & 2.7317 & .75827 & .575 & $\begin{array}{c}\text { Information Pouch } \\
\text { Paper }\end{array}$ & 123 & 3.0650 & 1.02221 & 1.045 \\
\hline Problem Solving & 123 & 3.9350 & .84679 & .717 & Interview & 123 & 3.1789 & 1.28058 & 1.640 \\
\hline Case Study & 123 & 3.9350 & .88466 & .783 & Socrates (Q\&A) & 123 & 2.2846 & .96258 & .927 \\
\hline Trip-Observation Studies & 123 & 3.6423 & 1.00922 & 1.019 & Question Network & 123 & 2.7073 & 1.03013 & 1.061 \\
\hline Simulation & 123 & 3.1382 & .90830 & .825 & What is the problem? & 123 & 2.9106 & 1.56293 & 2.443 \\
\hline Demostration & 123 & 2.5854 & 1.13749 & 1.294 & $\begin{array}{c}\text { Learning by } \\
\text { Discovery }\end{array}$ & 123 & 2.7480 & 1.30317 & 1.698 \\
\hline Discussion & 123 & 2.9024 & 1.12654 & 1.269 & Workshop & 123 & 2.2927 & .92976 & .864 \\
\hline Preparing Ven Schemes & 123 & 2.1301 & .87740 & .770 & Find Who & 123 & 2.9431 & .98597 & .972 \\
\hline Jigsaw Method & 123 & 1.7317 & .97571 & .952 & Sand Watch & 123 & 2.0407 & 1.03542 & 1.072 \\
\hline Computer Aided Teaching & 123 & 3.6667 & 1.12108 & 1.257 & Station & 123 & 2.2276 & .91269 & .833 \\
\hline
\end{tabular}




\begin{tabular}{|l|c|c|c|c|c|c|c|c|c|}
\hline Philipss 66 & 123 & 2.0081 & 1.05190 & 1.106 & Find Treasure & 123 & 1.9350 & .88466 & .783 \\
\hline Fish Worm & 123 & 3.2033 & 1.20762 & 1.458 & Learning Gallery & 123 & 2.6504 & .82961 & .688 \\
\hline Role Play & 123 & 2.7154 & 1.20464 & 1.451 & Snoball & 123 & 1.9431 & .88058 & .775 \\
\hline Pantomim & 123 & 3.0081 & 1.14158 & 1.303 & Buzz & 123 & 2.3984 & 1.12890 & 1.274 \\
\hline Poetry/Writing & 123 & 2.9593 & .93562 & .875 & Crossword & 123 & 2.3252 & .93647 & .877 \\
\hline Making Songs & 123 & 2.2033 & .85851 & .737 & Lotto & 123 & 2.4228 & .79967 & .639 \\
\hline Story Completion & 123 & 2.4878 & .76143 & .580 & $\begin{array}{c}\text { Aquarium (Inner } \\
\text { Circle) }\end{array}$ & 123 & 2.8130 & .93519 & .875 \\
\hline Find Title & 123 & 2.3008 & .92271 & .851 & Preparation of Annual & 123 & 2.2927 & .89380 & .799 \\
\hline Finding a Slogan & 123 & 2.6748 & .82478 & .680 & Letter Writing & 123 & 2.4878 & .88119 & .776 \\
\hline Ad Preparation & 123 & 3.1301 & 1.22112 & 1.491 & Summary & 123 & 2.6829 & 1.31397 & 1.727 \\
\hline Iconography & 123 & 3.0325 & 1.15896 & 1.343 & Evaluation Leaves & 123 & 2.7317 & 1.16699 & 1.362 \\
\hline Court & 123 & 2.5447 & 1.19598 & 1.430 & $\begin{array}{c}\text { Shared Teaching } \\
\text { (Synergy) }\end{array}$ & 123 & 3.4228 & 1.29948 & 1.689 \\
\hline Think, Discuss \& Share & 123 & 2.7724 & 1.10745 & 1.226 & $\begin{array}{c}\text { Teaching Through } \\
\text { Research }\end{array}$ & 123 & 3.2683 & 1.27442 & 1.624 \\
\hline Newspaper Publishing & 123 & 2.4472 & 1.04962 & 1.102 & $\begin{array}{c}\text { Hypothesis Building/ } \\
\text { Testing }\end{array}$ & 123 & 3.2683 & 1.19475 & 1.427 \\
\hline Press Conference & 123 & 3.5528 & .98516 & .971 & $\begin{array}{c}\text { Six Hat Concept of } \\
\text { Thinking }\end{array}$ & 123 & 3.3333 & 1.14996 & 1.322 \\
\hline Analogy (Metaphor) & 123 & 2.5772 & .98354 & .967 & $\begin{array}{c}\text { Comparing the } \\
\text { Rookies to the } \\
\text { Masters }\end{array}$ & 123 & 3.0407 & .97003 & .941 \\
\hline
\end{tabular}

\section{Copyrights}

Copyright for this article is retained by the author(s), with first publication rights granted to the journal.

This is an open-access article distributed under the terms and conditions of the Creative Commons Attribution license (http://creativecommons.org/licenses/by/4.0/). 